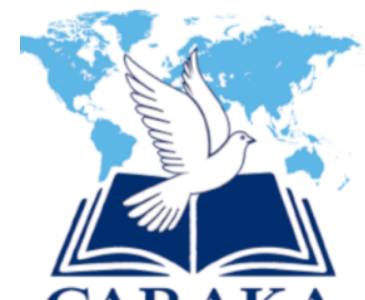

\title{
Makna Dibenarkan Oleh Iman Dan Perbuatan Menurut Yakobus 2:14-26
}

\author{
Samuel Julianta Sinuraya \\ Sekolah Tinggi Teologi Injil Bhakti Caraka Batam \\ Samuel.Sinuraya@sttibc.ac.id
}

\begin{abstract}
Since his fall into sin, man has suffered from moral depravity and self-image damage before God. God took the initiative to restore the relationship with humans through the redemptive work of Christ. Through Christ's redemption, mankind who was originally sinful was justified by God's grace. James wrote the teaching that man who is justified by God through faith, should have deeds according to their faith. This research is a qualitative research with a grammatical historical approach. The aim of this research is to find the meaning of being justified by faith and deeds according to James 2: 14-26 and to explain the implications for today's believers. For James, the true form of faith can be seen through works. This means that a person whose actions do not reflect Christ's righteousness is essentially dead.
\end{abstract}

Keywords: Justification; Faith and Deeds; James.

\begin{abstract}
Abstrak
Sejak jatuh ke dalam dosa, manusia mengalami kerusakan moral dan citra diri di hadapan Allah. Allah berinisiatif memulihkan hubungan dengan manusia melalui karya penebusan Kristus. Melalui penebusan Kristus, manusia yang semula berdosa dibenarkan oleh anugerah Allah. Yakobus menuliskan ajaran bahwa manusia yang sudah dibenarkan Allah oleh iman seharusnya memiliki perbuatan yang sesuai dengan imannya. Penelitian ini merupakan penelitian kualitatif dengan pendekatan historikal gramatikal. Adapun tujuan dari penelitian ini adalah menemukan makna dibenarkan oleh iman dan perbuatan menurut Yakobus 2:14-26 dan memaparkan implikasinya kepada orang percaya pada masa kini. Bagi Yakobus, bentuk iman yang sejati dapat dilihat melalui perbuatan. Seseorang yang perbuatannya tidak mencerminkan kebenaran Kristus pada hakekatnya mati.
\end{abstract}

Kata Kunci: Pembenaran; Iman dan perbuatan; Yakobus. 


\section{PENDAHULUAN}

Manusia adalah ciptaan Allah yang paling mulia dan kudus. Manusia diciptakan serupa dan segambar dengan Allah. Namun manusia jatuh dalam dosa dan semua orang telah berbuat dosa dan kehilangan kemuliaan Allah (Roma 3:23). Tony Lane menuliskan bahwa dosa secara tidak hormat telah menghina kemuliaan Allah. ${ }^{1}$ Marbun menuliskan bahwa dosa menyebabkan terputusnya persekutuan antara manusia dengan Allah dan alam semesta. ${ }^{2}$ Pandangan yang disampaikan Marbun memberikan kesan begitu besar dampak dari sebuah dosa.

Sejak peristiwa kejatuhan, Allah berinisiatif melakukan penebusan melalui Kristus. Kematian Kristus di kayu salib menjadi momen penebusan manusia dari dosa. Manusia yang semula berdosa dibenarkan melalui anugerah Allah semata. Handayani menuliskan bahwa konsep diselamatkan oleh anugerah (Sola Gratia) merupakan pembenaran yang dilakukan Allah kepada manusia. ${ }^{3}$ Pendapat Handayani menujukkan bahwa keselamatan yang diterima manusia merupakan pemberian Allah semata. French L Arrington berpendapat bahwa keselamatan adalah karya Allah dalam pengupayaan umat bebas dari perbudakan dosa dan membawanya ke situasi kemuliaan melalui Yesus Kristus. ${ }^{4}$ Pendapat Arrington memberikan petunjuk bahwa penebusan merupakan upaya pemulihan hubungan manusia dengan Allah yang telah rusak karena dosa.

Di dalam perkembangannya, pembenaran manusia memiliki beberapa pengajaran yang salah satunya ditemukan dalam Yakobus 2:14-26. Yakobus menuliskan bahwa manusia dibenarkan oleh karena iman dan perbuatan. Pandangan ini tentunya berbeda dengan teologi Paulus yang menuliskan manusia dibenarkan oleh karena iman saja. Paulus memahami pembenaran sebagai tindakan penyelamatan Allah secara eskatologis melalui karya penebusan Kristus. ${ }^{5}$ Bagaimanakah pembenaran menurut Yakobus dalam teks Yakobus 2:14-26? Apakah pembenaran juga harus disertai tindakan nyata sehari-hari? Tindakan seperti apakah yang dimaksudkan Yakobus sebagai bagian dari unsur pembenaran?

Berdasarkan penjelasan di atas, penulis bermaksud mencari makna dibenarkan oleh iman dan perbuatan menurut Yakobus 2:14-26. Adapun penulis melakukan penelitian ini untuk menemukan makna dibenarkan oleh iman dan perbuatan untuk dijadikan penjelasan dan pengajaran kepada orang percaya pada masa kini.

\footnotetext{
${ }^{1}$ Tony Lane, Anselmus Dalam Runtut Pijar: Tokoh Dan Pemikiran Kristen Dari Masa Ke Masa (Jakarta: BPK Gunung Mulia, 2016), 90.

2 Pardomuan Marbun, "Konsep Dosa Dalam Perjanjian Lama Dan Hubungannya Dengan Konsep Perjanjian," CARAKA: Jurnal Teologi Biblika dan Praktika 1, no. 1 (2020): 2.

${ }^{3}$ Dessy Handayani, "Tinjauan Teologis Konsep Iman Dan Perbuatan Bagi Keselamatan," EPIGRAPHE: Jurnal Teologi dan Pelayanan Kristiani 1, no. 2 (2018): 92.

${ }^{4}$ French L. Arrington, Doktrin Kristen: Perspektif Pentakosta (Yogyakarta: Penerbit Andi, 2015), 276.

${ }^{5}$ David Alinurdin, "Konsep Kebenaran Allah Menurut Rasul Paulus Di Dalam Surat Roma," Veritas : Jurnal Teologi dan Pelayanan 17, no. 1 (2018): 12.
} 


\section{METODE PENELITIAN}

Penelitian ini merupakan penelitian kualitatif dengan pendekatan historikal Gramatikal. Historikal gramatikal merupakan metode yang berhubungan dengan tata bahasa dan bagian dari penafsiran yang berguna untuk menemukan makna mula-mula dari sebuah teks. ${ }^{6}$ Di dalam penelitian ini, metode historikal gramatikal digunakan untuk menemukan makna dibenarkan oleh iman dan perbuatan menurut Yakobus 2:14-26. Adapun tahapan dalam penelitian ini adalah menemukan makna dibenarkan oleh iman dan perbuatan dalam teks Yakobus 2:14-26 dan menemukan implikasinya bagi orang percaya pada masa kini.

\section{HASIL DAN PEMBAHASAN}

\section{Latar Belakang Surat Yakobus}

Surat Yakobus ditujukan kepada orang-orang Kristen yang telah menyingkir dari Yerusalem karena penolakan yang mereka terima dari orang-orang Yahudi yang tidak menyukai kekristenan saat itu. Oleh sebab itu, Yakobus menuliskan surat ini untuk menjawab kebutuhan jemaat. Beberapa tujuan penulisan surat ini antara lain: Pertama, Yakobus ingin memberikan semangat kepada orang Kristen Yahudi yang mengalami penderitaan karena iman kepercayaannya kepada Kristus. ${ }^{7}$ Kedua, Yakobus berkeinginan kuat untuk memperbaiki berbagai pengertian yang salah dalam kehidupan orang percaya yang berkaitan dengan sifat iman yang menyelamatkan. ${ }^{8}$ Yakobus hendak menuntun setiap orang percaya untuk hidup secara bertangungjawab dalam kepercayaan iman yang benar di dalam Yesus Kristus.

\section{Dibenarkan Oleh Iman Menurut Yakobus 2:14-26}

\section{Iman Tanpa Perbuatan Tidak Berguna}

Yakobus mengatakan dalam ayat 14: "Apakah gunanya, saudara-saudaraku, jika seorang mengatakan bahwa ia mempunyai iman, padahal ia tidak mempunyai perbuatan? Dapatkah iman itu menyelamatkan dia?" Namun apabila dicermati secara mendalam, Yakobus dan Paulus tidak bertentangan, justru saling melengkapi.

"Pertama, Yakobus bukan menolak doktrin pembenaran oleh iman dari Paulus melainkan justru menolak penyimpangan terhadap doktrin tersebut. Kedua, Paulus dan Yakobus memakai kata perbuatan dan dibenarkan dengan pengertian yang berbeda."

\footnotetext{
${ }^{6}$ Dicky Dominggus, "Kedudukan Kristus Dalam Penciptaan Menurut Kolose 1:15-20 (Tanggapan Kristologi Saksi Yehuwa)," Religi: Jurnal Studi Agama-agama 16, no. 1 (2020): 45.

${ }^{7}$ Demsy Jura, "Mengenal Penulis Kitab Yakobus Dan Pengajarannya," Shanan Jurnal Pendidikan Agama Kristen 1, no. 1 (2017): 168.

${ }^{8}$ Ibid.

${ }^{9}$ Charles F Pfeiffer and Everett F. Harrison, The Wycliffe Bible Commentary Volume 3 (Malang: Gandum Mas, 2008), 89.
} 
Parafrase "jika seorang mengatakan bahwa ia mempunyai iman, padahal ia tidak mempunyai perbuatan?" menjelaskan bahwa iman yang sejati adalah iman yang disertai dengan perbuatan. Sedangkan yang dimaksud Yakobus dengan kata "perbuatan" disini, bukan perbuatan menurut pemahaman Yahudi yaitu sarana untuk memperoleh keselamatan. Namun perbuatan iman disini adalah hasil moral dari kesalehan sejati dan khususnya perbuatan kasih (Yak. 2:8). ${ }^{10}$ Jadi, jika seseorang mengatakan bahwa ia memiliki iman, harus ada buktinya, yakni dapat terlihat dari perbuatannya. Scheuemann menuliskan bahwa iman yang benar menghasilkan buah kehidupan, bukan iman yang hanya bersifat teoritis, namun tidak dinyatakan dalam kehidupan sehari-hari. ${ }^{11}$

Hal lain yang perlu diperhatikan juga adalah pertanyaan Yakobus dalam ayat 14b, yakni: "Dapatkah iman itu menyelamatkan dia?" Tentunya pertanyaan ini tidak mengharapkan sebuah jawaban, namun mengekspresikan rasa tidak puas Yakobus. Hal lain yang menjadi sebuah pertanyaan adalah, siapakah "dia" yang dimaksudkan Yakobus disini? Sangat mungkin "dia" ini menunjuk orang berkecukupan atau kaya yang mengklaim dirinya percaya Tuhan Yesus. ${ }^{12}$ Yakobus tidak melihat ada bukti yang dapat dilihat sebagai tanda bahwa orang tersebut adalah seorang yang beriman.

Yakobus 2:15-16 adalah sebuah penjelasan lanjutan dari ayat sebelumnya, yakni dengan mengatakan bahwa iman tanpa perbuatan tidaklah berguna. Adapun contoh yang diberikan adalah, apakah gunanya seorang yang mengatakan memiliki iman, tetapi tidak memiliki kasih dalam menolong saudara atau saudari yang tidak mempunyai pakaian dan kekurangan makanan. Makanan dan pakaian adalah kebutuhan dasar hidup manusia. Tuhan Yesus dalam Matius 25: 31-46 berbicara tentang penghakiman terakhir. Dalam nas ini, Yesus menyinggung perbuatan orang benar yang akan mendapat hidup yang kekal, seperti memberi pakaian pada yang telanjang, memberi makan kepada yang lapar, dan perbuatan baik lainnya, secara khusus kepada orang yang hina atau miskin. Jemaat gereja mula-mula terbiasa dengan praktek kasih seperti perduli serta menolong orang miskin dan janda. Namun sepertinya, Yakobus secara keras menegur jemaat Kristen yang tidak berbuat kasih.

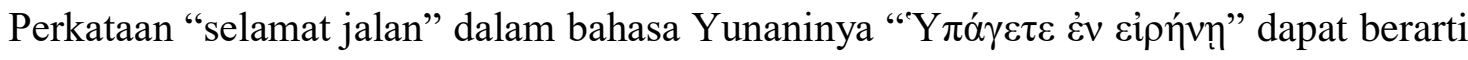
"pergilah dengan damai sejahtera."13 Pengertian lain dari perkataan ini adalah kiranya kemakmuran dan kebahagiaan terjadi atas mereka yang kepadanya diberikan salam. ${ }^{14}$

\footnotetext{
10 Ibid.

${ }^{11}$ Rainer Scheunemann, Tafsiran Surat Yakobus: Iman Dan Perbuatan, Menjadi Pelaku Dan Bukan Hanya Pendengar (Yogyakarta: Penerbit Andi, n.d.), 81.

${ }^{12}$ Hasan Sutanto, Surat Yakobus: Berita Perdamaian Yang Patut Didengar (Malang: SAAT, 2006), 205.

${ }^{13}$ Hasan Sutanto, Perjanjian Baru Interlinear Yunani-Indonesia Dan Konkordansi Perjanjian Baru Jilid I (Jakarta: Lembaga Alkitab Indonesia, 2010), 1212.

${ }^{14}$ Matthew Poole, A Commentary On The Holy Bible Vol.3 (USA: The Banner of Truth Trust, 1975),
} 886. 
Ungkapan ini sangat baik, namun menjadi tidak berguna ketika tidak diikuti dengan perbuatan kasih. Jika ada seorang Kristen yang hanya bagus dalam berkata-kata, namun tidak berbuat kasih, tidak ada gunanya. ${ }^{15}$ Pertanyaan Yakobus "apakah gunanya itu?", tidaklah membutuhkan sebuah jawaban, melainkan penegasan dari hal yang ingin disampaikannya, yakni Iman tanpa perbuatan tidak berguna.

Berdasarkan uraian di atas, yang dimaksudkan dengan iman tanpa perbuatan tidak berguna adalah tidak ada gunanya orang yang beriman jika ia tidak memiliki perbuatan kasih dalam menolong saudara atau saudari yang tidak mempunyai pakaian, kekurangan makanan dan yang sedang dalam kesusahan.

\section{Iman Tanpa Perbuatan Hakekatnya Mati}

Dalam ayat 17, Yakobus mengatakan iman tanpa perbuatan pada hakekatnya mati. James Adamson mengatakan bahwa sesuatu yang mati tidak dapat berbuah atau menghasilkan sesuatu, demikian juga iman yang mati tidak bisa menghasilkan perbuatan dari iman tersebut. ${ }^{16}$ Sebaliknya iman yang hidup, akan menghasilkan perbuatan dari iman tersebut seperti menghasilkan kasih dan perbuatan baik lainnya. Perbuatan bukanlah akar dari keselamatan, melainkan buahnya. William MacDonald mengatakan tidak ada iman yang benar dan yang hidup yang tidak menghasilkan perbuatan. ${ }^{17}$ Perbuatan bukanlah sebuah tambahan agar seseorang mendapat keselamatan, namun buah dari iman seseorang.

Dalam King James Version, kalimat “iman tanpa perbuatan adalah iman yang kosong” dalam Yakobus 2 : 20 adalah "that faith without work is dead." Kalimat ini sama halnya dengan ayat 17 di atas yang menegaskan tentang iman tanpa perbuatan pada hakekatnya mati.

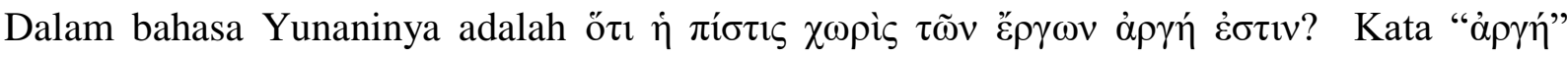
berasal dari kata argos yang disebutkan sebanyak 8 kali di Alkitab yang dapat berarti yang tidak bekerja; yang tidak mau bekerja; ceroboh. ${ }^{18}$ Yakobus ingin mengatakan bahwa iman yang asli selalu disertai dengan perbuatan. ${ }^{19}$

Gambaran contoh berikutnya dari iman tanpa perbuatan yang diberikan Yakobus adalah seperti tubuh tanpa roh adalah mati. Kata "tubuh" dalam bahasa Yunaninya adalah " $\sigma \tilde{\omega} \mu \alpha "$ yang dapat berarti tubuh; jenazah; bangkai; hamba; kenyataan. ${ }^{20}$ Sedangkan kata

15 James Adamson, The New International Commentary On The New Testament: The Epistle Of James (Grand Rapids Michigan: Zondervan Publishing, 1981), 124.

16 Ibid.

${ }^{17}$ William MacDonald, The Epistle Of James (USA: Emmaus Bible College, 1973),36.

${ }^{18}$ Hasan Sutanto, Perjanjian Baru Interlinear Yunani-Indonesia Dan Konkordansi Perjanjian Baru Jilid II (Jakarta: Lembaga Alkitab Indonesia, 2010), 111.

${ }^{19}$ John F Walvoord and Roy B. Zuck, The Bible Knowledge Commentary: An Exposition Of The Scriptures New Testament (USA: SP Publications, 1983), 826.

${ }^{20}$ Sutanto, Perjanjian Baru Interlinear Yunani-Indonesia Dan Konkordansi Perjanjian Baru Jilid II, 
"roh" dalam bahasa Yunaninya adalah " $\pi v \varepsilon v ́ \mu \alpha \tau o \varsigma$ ” yang berasal dari kata pneuma yang dapat berarti napas, angin, roh; sikap. ${ }^{21}$ Sedangkan kata "mati" dalam bahasa Yunaninya adalah

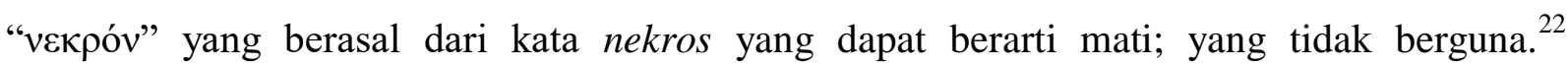
Penekanan Yakobus disini adalah satu tidak dapat hidup tanpa yang lain, dimana iman tanpa perbuatan seperti mayat yakni seperti tubuh tanpa roh. ${ }^{23}$ Jadi, iman yang sejati adalah iman yang terwujud lewat perbuatan kasih dan ketaatan kepada Allah. Perbuatan baik tidak membuat kita merasa layak berdiri di hadapan Allah, namun adalah bukti dari iman yang kita pegang. ${ }^{24}$ Ayat ini adalah sebuah kesimpulan dari ayat-ayat sebelumnya. Yakobus kembali lagi menggunakan perbandingan, dimana iman dan perbuatan tidak dapat dipisahkan. Yakobus tidak menyatakan secara langsung bahwa perbuatan adalah prinsip yang membuat iman menjadi hidup, namun iman dan perbuatan tidak dapat dipisahkan. ${ }^{25}$ Jika tidak ada buah dari iman, maka iman tersebut tidak lagi hidup, sama seperti tubuh tanpa roh adalah mati.

Yakobus 2 : 19, Yakobus mengatakan, "engkau percaya, bahwa hanya ada satu Allah saja? Itu baik! Tetapi setan-setanpun juga percaya akan hal itu dan mereka gemetar." Yakobus dalam suratnya sungguh menekankan bahwa seseorang yang memiliki iman tetapi tidak terlihat dalam perbuatan, sama dengan seseorang yang tidak memiliki iman sama sekali. Namun, lawan dialog Yakobus menetang lewat pengakuan iman mereka orang Yahudi, dengan mengatakan bahwa, "aku memiliki iman bahwa Allah adalah satu." 26 Monoteisme adalah kepercayaan dasar yang membedakan orang Yahudi dengan bangsa lain. ${ }^{27}$ Orangorang Yahudi memiliki pengakuan iman yang dikenal dengan nama "Shema" yang terdapat dalam Ulangan 6:4. Yakobus mengatakan bahwa hal itu baik, namun sayangnya setansetanpun juga percaya akan hal itu dan mereka gemetar. Mereka menganggap bahwa hanya dengan pengakuan iman yang benar sudah cukup untuk memperoleh keselamatan.

Yakobus mengatakan bahwa pengakuan iman mereka itu baik. Kata "itu baik" dalam

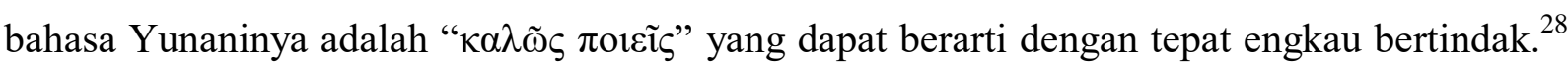
Hal ini membuktikan bahwa Yakobus tidak mempermasalahkan dan sama sekali tidak menentang pengakuan iman mereka. Namun sayang, Yakobus tidak menemukan bukti perbuatan yang sesuai dengan kehendak Allah dari iman mereka. Hal yang Yakobus ingin

${ }^{21}$ Ibid, 651 .

${ }^{22}$ Ibid, 532.

${ }^{23}$ Scheunemann, Tafsiran Surat Yakobus: Iman Dan Perbuatan, Menjadi Pelaku Dan Bukan Hanya Pendengar, 86.

${ }^{24}$ F Davidson, The New Bible Commentary (Illinois: Intervarsity Press, 1965), 1122.

${ }^{25}$ Frank E Gaebelein, The Expositors Bible Commentary Volume:12 (Grand Rapids Michigan: Regency Press, 1981), 185.

${ }^{26}$ Scheunemann, Tafsiran Surat Yakobus: Iman Dan Perbuatan, Menjadi Pelaku Dan Bukan Hanya Pendengar, 82.

${ }^{27}$ Sutanto, Surat Yakobus: Berita Perdamaian Yang Patut Didengar,206.

${ }^{28}$ Sutanto, Perjanjian Baru Interlinear Yunani-Indonesia Dan Konkordansi Perjanjian Baru Jilid I, 1213. 
sampaikan adalah, bahwa mereka hanya mementingkan komitmen intelektual dari iman saja, namun tidak pada komitmen secara personal untuk taat dan percaya. ${ }^{29}$

Yakobus membandingkan iman mereka dengan iman setan-setan, dengan mengatakan bahwa setan-setan juga percaya bahwa hanya ada satu Allah saja dan mereka gemetar. Analogi ini sungguh keras, secara khusus bagi orang Kristen yang berlatarbelakang Yahudi. Yakobus berharap agar mereka sadar bahwa sebagai orang Kristen harus menunjukkan bukti pengakuan iman lewat perbuatan kasih dan menaati kehendak Allah, tidak seperti layaknya setan-setan yang hanya percaya ada Allah dan gemetar, namun tidak menaati kehendak Allah. Iman sejati selalu disertai dengan perbuatan.

Berdasarkan uraian di atas, yang dimaksudkan dengan iman tanpa perbuatan pada hakekatnya mati adalah sebuah gambaran tentang iman dan perbuatan yang tidak boleh dipisahkan, dimana iman yang sejati adalah iman yang terwujud lewat perbuatan kasih dan ketaatan kepada Allah.

\section{Iman Bekerjasama Dengan Perbuatan}

Dalam ayat ini, Yakobus ingin menegaskan pentingnya mewujudkan iman dalam perbuatan. Yakobus sedang berhadapan dengan orang Kristen Yahudi yang memandang muka dan berpeluk tangan terhadap kebutuhan saudara seiman yang miskin. ${ }^{30}$ Yakobus mengatakan bahwa peran antara iman dan perbuatan saling bekerjasama. Kata "bekerjasama" dalam

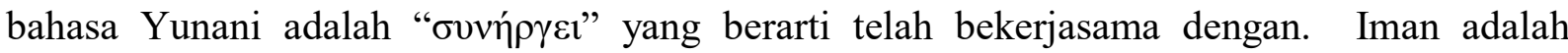
kekuatan yang mendorong sebuah tindakan. ${ }^{31}$ Jadi, iman adalah sumber dari sebuah tindakan, sehingga iman menghasilkan perbuatan.

Orang percaya yang memiliki iman kepada Allah, seharusnya melakukan apa yang menjadi kehendak Allah. Allah menghendaki agar orang Kristen untuk saling mengasihi, dan hal ini harus terwujud dalam tindakan. Iman yang sejati menunjukkan adanya sinergi antara iman dan perbuatan dalam kehidupan sehari-hari orang percaya. ${ }^{32}$

Dalam ayat 18, Yakobus membantah pendapat yang mencoba untuk memisahkan antara iman dengan perbuatan. Kemungkinan ada seseorang yang berpendapat bahwa iman kepercayaan dan perbuatan dapat dipisahkan. ${ }^{33}$ Seperti yang dijelaskan oleh Yakobus sebelumnya bahwa iman bekerjasama dengan perbuatan, jadi iman dan perbuatan tidak dapat

\footnotetext{
${ }^{29}$ Peter Davis, No TitleNew International Greek Testament Commentary: Commentary on James (Grand Rapids Michigan: William Eerdmans Publishing, 1973), 125.

${ }^{30}$ Sutanto, Surat Yakobus: Berita Perdamaian Yang Patut Didengar. 208.

${ }^{31}$ Walvoord and Zuck, The Bible Knowledge Commentary: An Exposition Of The Scriptures New Testament, 826.

${ }^{32}$ Scheunemann, Tafsiran Surat Yakobus: Iman Dan Perbuatan, Menjadi Pelaku Dan Bukan Hanya Pendengar, 83.

${ }^{33}$ Sutanto, Surat Yakobus: Berita Perdamaian Yang Patut Didengar, 206. 
dipisahkan. Iman yang sempurna adalah iman yang bekerjasama dengan perbuatan. Yakobus memberikan dialog hipotesis antara seseorang yang menentang pandangannya dengan dirinya untuk lebih memperjelas kesatuan antara iman dan perbuatan. ${ }^{34}$

Yakobus membantah pendapat mereka dengan sebuah tantangan, yakni dengan mengatakan "tunjukkan padaku imanmu itu tanpa perbuatan." Yakobus mempertanyakan kualitas iman mereka dan sekaligus menunjukkan bagaimana iman yang sesungguhnya itu. Jika seseorang mengatakan bahwa ia memiliki iman tetapi tidak memiliki perbuatan, maka akan sangat sulit untuk membuktikan iman yang ia miliki. Yakobus dapat membuktikan keberadaan dan kualitas imannya dari perbuatan-perbuatannya (tindakan dan tingkah laku). ${ }^{35}$ Dalam argumen ini, Paulus ingin mengatakan bahwa "perbuatan" itu penting untuk membuktikan bahwa seseorang itu memiliki iman. ${ }^{36}$

Iman adalah sesuatu yang tidak kelihatan. Satu-satunya cara agar orang lain dapat mengetahui bahwa seseorang memiliki iman adalah dengan mendemonstrasikannya dalam kehidupan sehari-hari melalui perbuatannya. ${ }^{37}$ Itulah sebabnya Yakobus mengatakan aku akan menunjukkan imanku dari perbuatan-perbuatanku. Iman yang tidak kelihatan harus dapat ditunjukkan dari perbuatan.

Yakobus mengatakan selanjutnya bahwa perbuatan-perbuatan itu membuat iman menjadi sempurna. Dengan kata lain, iman yang sempurna adalah iman yang disertai dengan

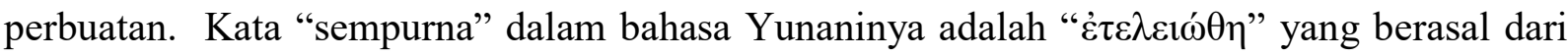
kata teleios yang berarti sempurna atau dewasa. Yakobus mengatakan apabila iman mereka ingin sempurna, maka iman itu harus disertai dengan perbuatan.

Orang percaya yang memiliki iman yang sempurna adalah mereka yang melakukan kehendak Allah. Perbuatan kasih dengan menolong orang-orang yang miskin adalah sebuah tindakan yang menyempurnakan iman mereka. Iman yang menghasilkan perbuatan baik sangatlah membesarkan hati. ${ }^{38}$ Iman yang sempurna adalah iman yang disertai dengan perbuatan.

Dimensi berikutnya dari iman tanpa perbuatan berdasarkan Yakobus 2:14-26 adalah iman nyata dalam perbuatan. Dimensi ini terbagi menjadi dua indikator, yakni: iman Abraham nyata dalam perbuatannya dan iman Rahab nyata dalam perbuatannya. Yakobus dalam penjelasan berikutnya memberi 2 contoh orang yang memiliki iman yang disertai dengan perbuatan, yakni Abraham seorang tokoh yang sangat dihormati oleh orang Yahudi dan Rahab

${ }^{34}$ Scheunemann, Tafsiran Surat Yakobus: Iman Dan Perbuatan, Menjadi Pelaku Dan Bukan Hanya Pendengar, 81 .

${ }^{35}$ Adamson, The New International Commentary On The New Testament: The Epistle Of James, 125.

${ }^{36}$ Gaebelein, The Expositors Bible Commentary Volume:12, 183.

${ }^{37}$ MacDonald, The Epistle Of James, 36.

${ }^{38}$ Poole, A Commentary On The Holy Bible Vol.3, 887. 
seorang tokoh yang bukan berasal dari bangsa Yahudi, namun ia dibenarkan Allah dari perbuatannya.

Abraham adalah tokoh yang sangat dihormati oleh bangsa Yahudi, oleh karena ia adalah bapa mereka. Yakobus menjelaskan bahwa Abraham dibenarkan karena perbuatannya, secara khusus ketika ia mempersembahkan Ishak. Perbuatan ketaatan Abraham kepada Allah adalah bukti dari iman yang dia miliki. Hal yang mendasari Abraham mempersembahkan anaknya adalah imannya kepada Allah. Abraham percaya dan melakukan apa yang Allah kehendaki. Dalam tradisi orang Yahudi, Abraham dikenal sebagai orang yang terbukti imannya melalui berbagai ujian. ${ }^{39}$ Jadi, iman Abraham terlihat nyata dalam perbuatannya. Abraham tidak hanya sekedar percaya, namun ia tunjukkan lewat perbuatan ketaatannya kepada Allah.

Yakobus memberikan contoh lain yang bukan dari orang Yahudi, yakni Rahab yang juga dibenarkan karena perbuatannya yang menolong umat pilihan Allah. Ayat ini tidak menuntut jawaban dari pembaca, namun untuk menyampaikan penegasan penulis. Dengan jelas Rahab disebut sebagai pelacur dan non Yahudi, namun wanita ini memiliki iman yang indah karena terwujud lewat tindakan dan terbukti pada pengakuannya tentang Allah yang benar. ${ }^{40}$ Tindakan yang berani dan tepat ini, membuat ia dihormati sama seperti Abraham. Sama halnya dengan Abraham, iman Rahab juga nyata dalam perbuatannya. Hal yang menjadi penekanan Yakobus dari contoh-contoh yang ia berikan di atas adalah bahwa iman tanpa perbuatan pada hakekatnya mati atau percuma, oleh sebab itu iman harus disertai dengan perbuatan. Itulah iman yang sejati atau sesungguhnya.

Berdasarkan penjelasan di atas, iman Abraham nyata dalam ketaatannya kepada Allah, rela berkorban dan melakukan perintah Allah. Sedangkan iman Rahab ditunjukkan lewat kesediaannya menolong orang lain dan memberikan tumpangan. Berdasarkan dua contoh yang ada, Yakobus sedang menjelaskan bukti iman yang disertai dengan tindakan nyata. Mariani Gea menuliskan bahwa iman dan perbuatan merupakan hal yang tidak dapat diselesaikan satu sama lain, melainkan saling melengkapi. ${ }^{41}$ Dalam pendapatnya, Mariani Gea sedang menunjukkan bahwa iman dan perbuatan merupakan dua hal yang saling berkaitan satu sama lain; seperti paket yang tidak terpisahkan.

\footnotetext{
${ }^{39}$ Sutanto, Surat Yakobus: Berita Perdamaian Yang Patut Didengar, 264.

${ }^{40}$ Ibid, 267.

${ }^{41}$ Yanti Imariani Gea, "Iman Orang Percaya Dalam Menghadapi Tantangan Dan Pergumulan Hidup," Immanuel: Jurnal Teologi dan Pendidikan Kristen 1, no. 1 (2020): 31.
} 


\section{Iman Menghasilkan Kasih}

Yakobus pada teks ini secara langsung memberikan definisi iman dalam perbuatan. Ungkapan Yakobus pada ayat 15-16 "Jika seorang saudara atau saudari tidak mempunyai pakaian dan kekurangan makanan sehari-hari, dan seorang dari antara kamu berkata: "Selamat jalan, kenakanlah kain panas dan makanlah sampai kenyang!", tetapi ia tidak memberikan kepadanya apa yang perlu bagi tubuhnya, apakah gunanya itu?" Ungkapan ini memberikan pemahaman kepada para pendengarnya, bahwa iman haruslah diwujudkan dalam perbuatan yang didasarkan oleh kasih. ${ }^{42}$ Ungkapan ini bukan hanya teguran kepada para pendengar atau pembaca masa itu melainkan kepada gereja hingga masa kini.

\section{Implikasi Bagi Orang Percaya Pada Masa Kini}

Allah telah menganugerahkan keselamatan atas semua manusia yang telah jatuh dalam dosa melalui kematian Yesus. Setiap orang berdosa yang percaya kepada Yesus dan yang mengaku dosanya mendapatkan anugerah pengampunan dan keselamatan. Allah menginginkan agar semua orang yang beriman kepada-Nya tidak lagi berbuat dosa. Iman dan perbuatan merupakan dua hal yang saling berkaitan dalam hal pembenaran yang dimaksudkan oleh Yakobus. Artinya, iman tidak dapat berdiri sendiri tanpa perbuatan begitu juga sebaliknya. Handayani menuliskan bahwa iman tanpa perbuatan adalah mati, sedangkan perbuatan tanpa iman merupakan dosa. ${ }^{43}$ Dari pendapat Handayani dapat dilihat adanya keterkaitan satu sama lain antara iman dan perbuatan.

Korelasi antara iman dan perbuatan dapat dipahami bahwa perbuatan merupakan implementasi dari iman seseorang terhadap keselamatan yang dimiliki. Artinya, orang percaya harus melakukan perbuatan sebagaimana layaknya seseorang yang telah diselamatkan. Jawamara menuliskan bahwa iman yang sejati dan menyelamatkan adalah iman yang bertumbuh secara progresif yang nyata dalam perbuatan. ${ }^{44}$ Pendapat yang sama dituliskan oleh Gidion yang menilai bahwa yang yang mengaku telah beriman dapat menunjukkan dalam perbuatan sehari-hari. ${ }^{45}$ Dari pandangan yang ada sangat jelas menunjukkan bahwa iman dapat diwujudkan dalam bentuk perbuatan sehari-hari.

Iman yang sejati adalah iman yang diwujudkan dalam tindakan yang nyata. Seorang yang beriman harus menunjukkan perbuatan kasih kepada sesamanya. Pada masa kini yakni covid 19, mengakibatkan banyak orang kehilangan pekerjaan dan pada akhirnya

\footnotetext{
${ }^{42}$ Aloys Budi Purnomo, Iman Sejati Versus Iman Kosmetik (Yogyakarta: Kanisius, 2005), 32.

${ }^{43}$ Handayani, "Tinjauan Teologis Konsep Iman Dan Perbuatan Bagi Keselamatan", 102.

${ }^{44}$ Markus Ndihi Jawamara, "Memahami Konsep Iman Dan Perbuatan Menurut Yakobus: Suatu Study Eksegesis Yakobus 2:26," SESAWI: Jurnal Teologi dan Pendidikan Kristen 1, no. 2 (2020): 121.

${ }^{45}$ Gidion Gidion, "Studi Biblika Korelasi Teologi Paulus Dan Teologi Yakobus Tentang Iman Dan Perbuatan Iman," Shift Key : Jurnal Teologi dan Pelayanan 8, no. 2 (November 2018): 14.
} 
mengakibatkan kesulitan dalam hal ekonomi. Sebagai seorang yang beriman, harus menunjukkan kepedulian terhadap mereka dengan tindakan yang nyata. Apabila ia memiliki berkat yang lebih, dapat memberikan bantuan berupa kebutuhan pokok dan kebutuhan lainnya. Selain itu, banyak juga orang yang mengalami ketakutan dan kecemasan. Dalam hal ini, seorang beriman dapat meluangkan waktu untuk memberikan penghiburan, kekuatan serta doa bagi mereka yang mengalaminya.

Situasi saat ini menjadikan kasih merupakan satu-satunya penawar dari pengharapan yang mulai meredup atau menghilang. Sebagai orang percaya kita haruslah mewujudkan iman dalam perbuatan yang didasarkan oleh kasih. Mengapa demikian? karena setiap orang Kristen adalah Gereja yang hidup, Gereja yang bergerak, dan lebih lagi merupakan representatif dari Tuhan Yesus.

\section{KESIMPULAN}

Kejatuhan manusia ke dalam dosa telah mengubah natur manusia yang semula kudus menjadi makhluk yang cenderung berbuat dosa. Dalam hal relasi manusia mulanya bergaul karib dengan Allah kini menjadi terpisahkan, manusia makhluk yang berdosa dan Allah sebagai pribadi yang kudus. Manusia tidak layak menjumpai Allah dan sebaliknya Allah terlalu mulia untuk bersekutu dengan manusia. Keadaan ini mendorong Allah untuk melakukan penebusan melalui Kristus.

Kematian Kristus di kayu salib menjadi peristiwa penebusan manusia dari dosa. Manusia yang sejatinya binasa karena dosa menjadi selamat karena penebusan Kristus. Untuk dapat memaknai penebusan Yesus, orang percaya harus menghayatinya melalui iman dan tindakan. Artinya, kehidupan orang percaya harus bertolak dari iman dan dinyatakan dalam kehidupan sehari-hari. Kehidupan orang percaya menjadi cerminan sebagai orang-orang yang sudah dibenarkan oleh iman. Jadi, hal ini yang dimaksudkan oleh Yakobus 2:14-26 bahwa manusia dibenarkan oleh iman dan perbuatan.

\section{DAFTAR PUSTAKA}

Adamson, James. The New International Commentary On The New Testament: The Epistle Of James. Grand Rapids Michigan: Zondervan Publishing, 1981.

Alinurdin, David. "Konsep Kebenaran Allah Menurut Rasul Paulus Di Dalam Surat Roma." Veritas : Jurnal Teologi dan Pelayanan 17, no. 1 (2018): 1-14.

Arrington, French L. Doktrin Kristen: Perspektif Pentakosta. Yogyakarta: Penerbit Andi, 2015.

Davidson, F. The New Bible Commentary. Illinois: Intervarsity Press, 1965.

Davis, Peter. No TitleNew International Greek Testament Commentary: Commentary on James. Grand Rapids Michigan: William Eerdmans Publishing, 1973. 
Dominggus, Dicky. "Kedudukan Kristus Dalam Penciptaan Menurut Kolose 1:15-20 (Tanggapan Kristologi Saksi Yehuwa).” Religi: Jurnal Studi Agama-agama 16, no. 1 (2020): 42-63.

Gaebelein, Frank E. The Expositors Bible Commentary Volume:12. Grand Rapids Michigan: Regency Press, 1981.

Gea, Yanti Imariani. "Iman Orang Percaya Dalam Menghadapi Tantangan Dan Pergumulan Hidup." Immanuel: Jrnal Teologi dan Pendidikan Kristen 1, no. 1 (2020): 25-32.

Gidion, Gidion. "Studi Biblika Korelasi Teologi Paulus Dan Teologi Yakobus Tentang Iman Dan Perbuatan Iman." Shift Key: Jurnal Teologi dan Pelayanan 8, no. 2 (November 2018): 1-15.

Handayani, Dessy. "Tinjauan Teologis Konsep Iman Dan Perbuatan Bagi Keselamatan." EPIGRAPHE: Jurnal Teologi dan Pelayanan Kristiani 1, no. 2 (2018): 91-103.

Jawamara, Markus Ndihi. "Memahami Konsep Iman Dan Perbuatan Menurut Yakobus: Suatu Study Eksegesis Yakobus 2:26." SESAWI: Jurnal Teologi dan Pendidikan Kristen 1, no. 2 (2020): 111-125.

Jura, Demsy. "Mengenal Penulis Kitab Yakobus Dan Pengajarannya." Shanan Jurnal Pendidikan Agama Kristen 1, no. 1 (2017): 158-178.

Lane, Tony. Anselmus Dalam Runtut Pijar: Tokoh Dan Pemikiran Kristen Dari Masa Ke Masa. Jakarta: BPK Gunung Mulia, 2016.

MacDonald, William. The Epistle Of James. USA: Emmaus Bible College, 1973.

Marbun, Pardomuan. "Konsep Dosa Dalam Perjanjian Lama Dan Hubungannya Dengan Konsep Perjanjian.” CARAKA: Jurnal Teologi Biblika dan Praktika 1, no. 1 (2020): 116.

Pfeiffer, Charles F, and Everett F. Harrison. The Wycliffe Bible Commentary Volume 3. Malang: Gandum Mas, 2008.

Poole, Matthew. A Commentary On The Holy Bible Vol.3. USA: The Banner of Truth Trust, 1975.

Scheunemann, Rainer. Tafsiran Surat Yakobus: Iman Dan Perbuatan, Menjadi Pelaku Dan Bukan Hanya Pendengar. Yogyakarta: Penerbit Andi, n.d.

Sutanto, Hasan. Perjanjian Baru Interlinear Yunani-Indonesia Dan Konkordansi Perjanjian Baru Jilid I. Jakarta: Lembaga Alkitab Indonesia, 2010.

—. Perjanjian Baru Interlinear Yunani-Indonesia Dan Konkordansi Perjanjian Baru Jilid II. Jakarta: Lembaga Alkitab Indonesia, 2010.

- Surat Yakobus: Berita Perdamaian Yang Patut Didengar. Malang: SAAT, 2006.

Walvoord, John F, and Roy B. Zuck. The Bible Knowledge Commentary: An Exposition Of The Scriptures New Testament. USA: SP Publications, 1983. 